Volume 15 Nomor 2, Desember 2019

\title{
Pengaruh Pengalaman dan Akuntabilitas Terhadap Kualitas Audit Internal
}

\author{
U s m a n \\ Universitas Negeri Gorontalo \\ usmanpattiwi@gmail.com
}

\begin{abstract}
:
This study aims to determine the effect of work experience and accountability of internal auditors on the quality of internal audit. Supervision of regional government operations is carried out in stages starting from the Regency / City, Province to the Central level. The independent variables in this study are work experience and accountability. While the dependent variable in this study is the quality of internal audit. it is based on several literature studies and the results of previous studies, the results of this study indicate that work experience and accountability have a very strong role in determining the quality of internal audit, and if someone does the same work repeatedly or continuously, it will be faster and more professional in completing internal audits properly, This is because the auditor has truly understood the techniques or how to properly complete the audit and be careful in completing the audit as expected, therefore the auditor's experience and internal auditor's accountability in carrying out the audit can improve the quality of internal audit.
\end{abstract}

Keyword: Work Experience, Accountability, Internal Audit Quality.

\section{A. PENDAHULUAN}

Audit internal dilakukan oleh unit khusus dalam suatu unit organisasi yang independen terhadap unit-unit organisasi lain yang diaudit dan dilakukan untuk kepentingan manajemen organisasi (andayani, 2008:01). Senada dengan hal tersebut audit internal menurut Arens (816:2012) dinyatakan bahwa Internal auditing is an independent, obyektive assurance and consulting activity designed to add value and improve an organization's operations. It helps and organization accomplish its objectives by bringing a systematic, disciplined approach to valuate and improve the effectiveness of risk management, control, and governance processes. 
Agoes (2013:04) mengatakan bahwa auditing adalah suatu pemeriksaan yang dilakukan secara kritis dan sistematis, oleh pihak yang independen, terhadap laporan keuangan yang telah disusun oleh manajemen, beserta catatan pembukuan dan buktibukti pendukungnya, dengan tujuan untuk dapat memberikan pendapat mengenai kewajaran laopran keuangan tersebut. Demikian pula beberapa hal yang penting dibahas lebih lanjut menurut Agoes (2013) tentang auditing yakni yang pertama laporan keuangan yang telah disusun oleh manajemen beserta catatan-catatan pembukuan dan bukti-bukti pendukungnya, kedua pemeriksaan dilakukan secara kritis dan sistematis, akuntan publik harus dapat merencanakan pemeriksaannya sebelum proses pemerksan dimulai dengan membuat rencana pemeriksaan. Agar pemeriksaan dapat dilakukan secara kritis, pemeriksaan tersebut harus dipimpin oleh seorang yang mempunyai register accountant dan mempeunyai izin praktek sebagai akuntan public dari menteri keuangan.

Pemeriksaan haruslah seorang yang mempunyai pendidikan, pengalaman, dan keahlian dibidang akuntansi, perpajakan, sistem akuntansi dan pemeriksaan akuntan. Namun jika akuntan public dan audit stafnya tidak mempunyai keahlian tersebut maka tidak akan mungkin pemeriksaan dilakukan secara kritis (cermat, hati-hati dan waspada terhadap kemungkinan terjadinya penyimpangan, salah saji material atau kesalahan). Ketiga, pemeriksaan dilakukan oleh pihak yang independen yakni akuntan public dalam artian bahwa sebagai pihak diluar perusahaan yang diperiksa tidak boleh mempunyai kepentingan tertentu didalam perusahaan tersebut dengan demikian akuntan publik harus independen, bekerja secara obyektive, tidak memihak kepada pihak manapun dan melaporkan apa adanya. Kempat, tujua daripada pemeriksaan akuntan yakni untuk dapat memebrikan pendapat mengenai pendapat kewajaran laporan keuangan yang disusun berdasarkan prinsip akuntansi yang diterima secara umum yang diterapkan secara konsisten dan tidak mengandung kesalahan yang material dan akuntan public tidak dapat menyatakan bahwa laporan keuangan itu benar, karena pemeriksaannya dilakukan secara sampling sehingga mungkin saja terdapat kesalahan dalam laporan keuangan tetapi jumlahnya tidak material sehingga tidak mempengaruhi kewajaran laporan keuangan secara keseluruhan. Akan tetapi hal tersebut perusahaan kecil dan menengah bisa 
memilih dengan menggunakan Entitas Tanpa Akuntabilitas Publik (ETAP) atau PSAK sebagagai dasar penyusunan laporan keuangannya, dan saat ini untuk perusahaan besar dan public company harus menggunakan PSAK dan mulai tahun 2012 menggunakan International Financial Reforting Standard (IFRS).

Menurut Peraturan Menteri Negara Pendayagunaan Aparatur Negara Indonesia nomor PER/05/M.PAN/03/2008, pengukuran kualitas audit atas laporan audit yang dilakukan oleh Aparat Pengawas Intern Pemerintah (APIP) bahwa wajib menggunakan Standar audit Aparat Intern Pengawas Pemerintah (SA-APIP). Audit yang berkualitas adalah audit yang dapat ditindaklanjuti oleh auditee. Kualitas ini harus dibangun sejak awal pelaksanaan audit hingga pelaporan dan pemberian rekomendasi. APIP dalam menjalankan tugasnya harus memegang prinsip-prinsip profesi, sebagaimana telah diatur dalam Peraturan Menteri Negara Pendayagunaan Aparatur Negara nomor PER/05/M.PAN/03/2008 tentang kode etik APIP.

Dalam Standar Profesional Akuntan Publik (SPAP) bahwa persyaratan yang dituntut dari auditor independen adalah orang yang memiliki pendidikan dan pengalaman yang memadai yang biasanya diperoleh dari praktik-praktik dalam bidang auditing sebagai auditor independen, demikian pula bahwa pengalaman mempunyai hubungan yang erat dengan keahlian auditor, pencapaian keahlian seorang auditor selain berasal dari pendidikan formalnya juga diperluas lagi dengan pengalaman-pengalaman dalam praktik audit. Dalam penelitian oleh Sembiring (2014), menunjukan bahwa pengalaman auditor internal secara parsial berpengaruh positif terhadap kualitas audit internal. Selanjutnya Auditor harus melaksanakan pemeriksaan sesuai dengan standar yakni pengalaman dan kualitas audit seperti peneltitian yang dilakukan oleh Yuliyanti (2006) mengemukakan bahwa pengalaman dengan arah positif berpengaruh signifikan terhadap kualitas audit.oleh karena itu hal tersebut diatas dapat dpahami bahwa semakin banyak jumlah jam terbang seorang auditor, tentunya dapat memberikan kualitas audit yang lebih baik dari pada seorang auditor yang baru memulai kariernya. Atau dengan kata lain auditor yang berpengalaman diasumsikan dapat memberikan kualitas audit yang lebih 
baik dibandingkan dengan auditor yang belum berpengalaman. Hal ini dikarenakan pengalaman akan membentuk keahlian seseorang baik secara teknis maupun secara psikis

Pusdiklat BPKP (2007), memandang bahwa Semakin meningkatnya tuntutan masyarakat terhadap penyelenggaraan pemerintahan yang baik dan bersih (good governance dan clean government) telah mendorong pengembangan dan penerapan sistem pertanggungjawaban yang jelas, tepat, teratur, dan efektif yang dikenal dengan Sistem Akuntabilitas Kinerja Instansi Pemerintah (SAKIP). Menurut Badan Pemeriksaan Keuangan dan Pembangunan, Akuntabilitas dipandang sebagai perwujudan kewajiban seseorang atau unit organisasi untuk mempertanggungjawabkan pengelolaan sumber daya dan pelaksanaan kebijakan yang dipercayakan kepadanya dalam rangka pencapaian tujuan yang telah ditetapkan melalui media pertanggungjawaban berupa laporan akuntabilitas kinerja secara periodik. Hal demikan hasil penelitian dari Yuliyanti (2006) mengungkapkan pula bahwa akuntabilitas dengan arah positif berpengaruh signifikan terhadap kualitas audit. Dan Muliani Singgih (2010) mengatakan bahwa akuntabilitas mempunyai pengaruh terhadap kualitas audit internal. Berdasarkan penelitian tersebut diatas dapat disimpulkan bahwa akuntabilitas sangat penting pada seseorang dalam melakukan pekerjaan untuk menentukan sebuah proses informasi, dan hasil informasi tersebut akan dapat menpengaruhi perilaku untuk pengambilan keputusan.

\section{B. LITERATURE REVIEW}

\section{Audit}

Audit Menurut Peraturan Menteri Negara Pendayagunaan Aparatur Negara Nomor PER/05/M.PAN/03/2008, adalah suatu proses identifikasi masalah, analisis, dan evaluasi bukti yang dilakukan secara independen, obyektif dan profesional berdasarkan standar audit, untuk menilai kebenaran, kecermatan, kredibilitas, efektifitas, efisiensi, dan keandalan informasi pelaksanaan tugas dan fungsi instansi pemerintah. Sedangkan menurut Mayangsari (2013) bahwa yang dimaksud dengan auditing adalah suatu proses 
yang sitematis untuk menperoleh dan menilai bukti-bukti secara obyektif, yang berkaitan dengan asersi-asersi tentang tindakan-tindakan dan kejadian-kajadian ekonomi untuk menentukan tingkat kesesuaian antara asersi-asersi tersebut dengan kriteria yang telah ditetapkan dan dikomunikasikan hasilnya kepada pihak-pihak yang berkepentingan. Hal tersebut mengandung arti secara luas dan berlaku untuk segala macam jenis auditing atau pengauditan yan memiliki tujuan yang berbeda-beda.

Auditing merupakan suatu pengumpulan dan evaluasi bukti tentang inforamasi untuk menentukan dan melaporkan derajat kesesuaian antara informasi itu dan kriteria yang telah ditetapkan. Dan auditing harus dilakukan oleh orang yang kompoten dan independen (Arens,2012). Sedangkan auditing menurut Agoes (2013) adalah merupakan suatu pemeriksaan yang dilakukan secra kritis dan sistematis, oleh pihak yang independen, terhadap laporan keuangan yang telah disusun oleh manajemen, beserta catatan-catatan pembukuan dan bukti-bukti pendukungnya, dengan tujuan untuk dapat memberikan pendapat mengenai kewajaran laporan keuangan tersebut.

Audit internal menurut Tugiman (2006) dalam Andayani (2008:04) menyatakan bahwa audit internal dapat memberikan berbagai jenis layanan kepada oreganisasi. Yaitu membantu mengevaluasi aktivitas dalam bidang, (1) pengendalian akuntansi intern, (2) pencegahan dan pendeteksian kecurangan, (3) pemeriksaan keuangan, (4) Pemeriksaan Ketaatan, ( pemeriksaan operasional, (6) Pemeriksaan manajemen, (7) Pemeriksaan Kontrak, (8) Pemeriksaan sistem informasi, (9) Pengembangan kualitas internal dan (10) hubungan dengan entitas diluar perusahaan. Jadi kualitas audit internal suatu proses sejauh mana mengaudit dan mengkomunikasikan hasil-hasilnya untuk memenuhi harapan bagi pemakai. Hal yang sama terungkap pada badan organisasi Institute of internal Auditor (IIA) dalam Kurt F (2009:02) bahwa internal auditing is an independent, objective assurance and consulting activity designed to add value and improve an arganization's operations. It helps an organization accomplish its objektives by bringing a systematic, disciplined approach to evaluate and improve the effectiviness of risk management, control, and governance processes. 
Dennis R. Arter (2003:130) mengemukakan bahwa kualitas Audit internal membahas tentang aspek kualitas produk, proses atau sistem. Demikian pula halnya bahwa kualitas audit dapat dirancang khusus untuk menentukan apakah produk itu memenuhi standar estabilished oleh manajemen menurut louwers (2008:631), oleh karena itu kualitas Audit dapat melakukan suatu proses sejauh mana mengaudit dan mengkomunikasikan hasil-hasilnya untuk memenuhi harapan konsumen (Rick Hayes, 2005:51). The IIA mendefinisikan audit internal merupakan jaminan kegiatan dan konsultasi yang independen dan objektif yang dirancang untuk menambah nilai untuk dapat meningkatkan operasi organisasi, Yass Alkafaji \& Shakir Hussain, (2010:27). Sedangkan Karla M. Johnstone, (2014) mendefinisikan kualitas audit dapat mengidentifikasi dan merupakan suatu penggerak dari kualitas audit sebagaimana ditentukan oleh pengguna terhadap kerangka pelaporan keuangan dan kerangka Audit Kualitas.

Dalam memahami kualitas audit yang telah dikemukakan oleh para ahli maka untuk selanjutnya definisi kualitas audit internal sangat penting untuk diketahui dalam suatu organisasi untuk menguji dan mengevaluasi kegiatan organisasi yang dilaksanakan. oleh karena itu kualitas audit internal menurut Moeller (1999: 553) adalah pemeriksaan internal dilakukan secara berkala, dan dengan cara yang sama seperti audit internal lainnya, oleh anggota staf audit internal untuk menilai kualitas pekerjaan audit yang dilakukan, selanjutnya kualitas audit internal dengan hal yang sama oleh Moeller (2005:655) serta kualitas audit internal merupakan langkah pertama diperlukan untuk memulai sebuah fungsi audit internal yang berkualitas, sedangkan menurut Tugiman (1997:11) bahwa internal audit atau pemeriksaan internal adalah suatu fungsi penilaian yang independen dalam suatu organisasi untuk menguji dan mengevaluasi kegiatan organisasi yang dilaksanakan. Selanjutnya pemeriksaan internal merupakan bagian organisasi yang integral dan menjalankan fungsinya berdasarkan kebijaksanaan yang telah ditetapkan oleh manajemn senior atau dewan direksi dan pernyataan tentang tujuan, kewanangan, dan tanggung jawab bagian audit internal yang disetujui oleh manajemen senior dan diterima oleh dewan atau direksi wajib konsisten dengan kodefikasiyang 
berupa norma praktek professional audit internal, demikian pula bahwa kegiatan pemeriksaan internal auditing dilaksanakan dalam berbagai lingkungan yang berbedabeda dan dalam organisasi-organisasi dengan mempunyai tujuan, ketentuan, serta kebiasaannya yang tidak sama, maka akan mempenagruhi pelaksanaan pemeriksaan internal dimasing-masing linkungan.

Hal demikian juga yang berkaitan dengan audit internal pada pemerintahan daerah sangat penting untuk dapat dipahami dalam konteks kualitas audit intenal khusunya menyankut audit sector publik sebagaimana uraian berikut:

\section{a. Audit Sektor Publik}

Audit sector public menurut Bastian (2014) mendefinisikan bahwa suatu proses`sistematik secara objektif untuk melakukan pengujian keakuratan dan kelengkapan informasi yang disajikan dalam suatu laporan keuangan organisasi sector public. Dan selanjutnya proses pengujian ini memungkinkan akuntan public independen yang bersertifikasi mengeluarkan suatu pendapat atau opini mengenai seberapa baik laporan keuangan organisasi mewakili posisi keuangan organisasi sector public dan apakah laporan keuangan tersebut memenuhi prinsip-prinsip akuntansi yang berterima umum atau generally Accepted Accounting principles (GAAP).

\section{b. Auditor Internal Pemerintah}

Auditor internal dipegang oleh Badan Pengawasan Keuangan dan Pembangunan (BPKP), Inspektorat Jenderal atau nama lain yang secara fungsional melaksanakan pengawasan intern, Inspektorat Provinsi, dan Inspektorat Kabupaten atau Kota. Dan menurut Permenpan No. PER/05/M.PAN/03/2008 menyatakan bahwa: "Auditor intern adalah pegawai negeri sipil yang mempunyai jabatan fungsional auditor dan/atau pihak lain yang diberi tugas, wewenang, tanggung jawab dan hak secara penuh oleh pejabat yang berwenang melaksanakan pengawasan pada instansi pemerintah untuk dan atas nama APIP. Sedangkan menurut Arens (2005) mengatakan bahwa "Internal auditor 
adalah seseorang yang bekerja sebagai karyawan suatu organisasi untuk melakukan audit bagi kepentingan manajemen".

Menurut Mulyadi (2002:416) menyatakan bahwa auditor dapat memilih beberapa tipe pendapat yang akan dinyatkan atas laporan keuangan auditan diantaranya a) pendapat waja tanpa pengecualian, b). pendapat wajar tanpa pengecualian dengan bahasa penjelasan yang ditambahkan dalam laporan audit baku. c). pendapat wajar dengan pengecualian d). pendapat tidak wajar dan e). pernyataan tidak memberikan pendapat.

Auditor Inspektorat melakukan proses audit terhadap pemerintah daerah, kemudian dari hasil tersebut diberikan pada Gubernur. Pihak BPK melakukan pemeriksaan atas laporan hasil audit yang telah dibuat oleh auditor inspektorat, agar BPK dapat mengeluarkan opini terhadap laporan hasil audit yang telah dibuat tersebut. Maka, hasil audit auditor inspektorat menjadi 'second opinion' bagi BPK dalam melakukan proses audit.

Standar Audit Aparat Pengawasan Intern Pemerintah (SA-APIP) di indinesia Merupakan revisi atas Standar Audit Aparat Pengawasan Fungsional Pemerintah yang disusun oleh Badan Pengawas Keuangan dan Pembangunan (BPKP) tahun 1996. Dalam undang-undang Nomor 15 Tahun 2004 tentang Pemeriksaan Pengelolaan dan Tanggungjawab Keuangan Negara, diatur tentang Pemeriksaan Pengelolaan dan Tangungjawab keuangan Negara yang dilakukan oleh dan atau atas nama Badan Pemeriksaan Keuangan (pasal 1 butir (3)). Karena APIP adalah auditor intern dalam lembaga eksekutif dan dibentuk untuk membantu pimpinan dilingkungan lembaga eksekutif, baik di tingkat Presiden, Menteri, Kepala Lembaga Pemerintah Non Departemen (LPND) sampai ke tingkat pemerintah daerah Provinsi, Kabupaten dan Kota.

\section{Pengalaman Auditor Internal}

Pengalaman auditor yang memadai adalah penting dalam rangka memberikan pertimbangan tingkat materialitas dalam proses pengauditan. Hal ini disebabkan karena hingga saat ini belum terdapat standar baku mengenai dasar penetapan tingkat materialitas. Auditor dapat menggunakan pengalamannya sebagai dasar untuk 
memberikan pertimbangan tingkat materialitas.hal tersebut seorang auditor sangat penting dalam mengikuti pelatihan-pelatihan audit secara teknis sebagaimana dikemukakan oleh Mulyadi (2002:25) bahwa seorang auditor harus dapat menjalani pelatihan teknis yang cukup dalam praktik akuntansi dan prosedur audit. Pendidikan formal akuntan publik dan pengalaman kerja dalam profesinya merupakan duahl yang saling melengkapi. Oleh karena itu, jika seorang memasuki karier sebagai akuntan publik, ia harus lebih dulu mencari pengalaman profesi dibawah pengawasan akuntan senior yang lebih berpengalaman. Bahkan agar akuntan yang baru selesai menempuh pendidikan formalnya dapat segera menjalani pelatihan teknis dalam profesinya, pemerintah mensyaratkan pengalaman kerja sekurang-kurangnya tiga tahun sebagai akuntan dengan reputasi baik di bidang audit bagi akuntan yang ingin memperoleh izin praktik dalam profesi akuntan publik di indonesia (SK Menteri Keuangan No.43/KMK.017/1997 tanggal 27 Januari 1997).

Hal selanjutnya yang disinggung oleh Mulyadi (2002:125) mengenai tentang review terhadap pengalaman auditor dimasa lalu dalam berhubungan dengan klien yang bersangkutan maka auditor harus dapat menpertimbangkan untuk melanjutkan atau menghentikan hubungan dengan klien dalam perikatan audit, auditor harus secara seksama menpertimbangkan pengalamannya dimasa lalu dalam berhubungan dengan klien dalam perikatan audit. Seperti auditor perlu menpertimbangkan adanya kekeliruan atau kecurangan dan pelanggaran hokum yang dilakukan oleh klien yang ditemukan dalam audit atas laporan keuangan tahun yang lalu sehingga auditor dapat mengajukan berbagai peertanyaan kepada manajemen tentang adanya hal-hal bersyarat, kelengkapan notulen rapat dewan komisaris, kepatuhan klien terhadap peraturan pemerintah. Oleh karena itu kebenaran jawaban yang diberikan oleh manajemen dalam audit laporan keuangan tahun yang lalu, harus dipertimbangkan dalam mengevaluasi integritas manajemen.

Pengalaman kerja menurut SPAP (2001), dalam standar Umum pertama Indonesia PSA No.4, yaitu dalam melaksanakan audit untuk sampai pada suatu pernyataan pendapat, auditor harus senantiasa bertindak sebagai seorang ahli dalam bidang akunansi 
dan bidang auditing. Pencapaian keahlian dimulai dengan pendidikan formalnya, yang diperluas melalui pengalaman-pengalaman selanjutnya dalam praktik audit. Pengalaman kerja auditor adalah pengalaman dimiliki auditor dalam melakukan audit yang dilihat dari segi lamanya bekerja sebagai auditor dan banyaknya tugas pemeriksaan yang telah dilakukan.

Pengalaman auditor intern Secara umum dapat dilihat dari jenjang karier internal audit dengan pengalaman bekerja bergantung pada kebijakan masing-masing manajemen perusahaan menurut Kaunang (2012:07). Oleh karena itu staf audit sebaiknya memiliki latar belakang pendidikan spesialisasi bidang akuntansi, atau bidang pendidikan lain dengan catatan mempunyai pengalaman yang cukup dan mengerti bisnis perusahaan dengan baik, atau lebih mengenal secara spesifik industry perusahaan terserbut.

\section{Akuntabilitas Audit Internal}

Mayangsari (2013) mengungkapkan bahwa dalam menpertanggungjawabkan kekayaan, manajemen perusahaan atau manajemen pemerintah menggunakan akuntansi sebagai bahasa komunikasi. Untuk itu manajemen perlu menyelenggarakan akuntansi yang memungkinkan disajikannya laporan pertanggungjawaban keuangan kepada para pemilik. Pertanggungjawaban keuangan memerlukan dua unsur, yaitu unsur kompetensi, dalam bidang akuntansi dan keandalan informasi akuntansi yang dihasilkan. Demikian pula mengenai tentang laporan keuangan, disamping sebagai alat pertanggungjawaban keuangan juga merupakan alat komunikasi antara perusahaan atau pemerintah dengan pihak-pihak yang berkepentingan.

Laporan keuangan yang dihasilkan oleh perusahaan atau pemerintah harus diperiksa atau di audit oleh akuntan public atau auditor independen, sehingga laporan keuangan tersebut dapat diandalkan dan dapat diartikan dengan bahasa yang sama oleh pihak-pihak yang berkepentingan dengan perusahaan atau pemerintah tersebut, karena laporan keuangan tersebut sudah diverifikasi dan ditelusuri sampai kepada bukti-bukti pendukungnya dan telah ditentukan tingkat kesesuainnya dengan kriteria yang telah ditetapkan. Oleh karena itu hal yang sangat perlu dipahami bahwa pada dasarnya semakin 
kompleks perekonomian suatu masyarakat, maka semakin kompleks transaksi keuangan yang dilakukan oleh masyarakat tersebut, sehingga membutuhkan kompetensi yang tinggi untuk mencerminkan transaksi keuangan mereka dengan informasi akuntansi. Di samping itu, pertanggungjawaban keuangan kepada para pemilik membutukan informasi akuntansi yang tinggi tingkat keandalannya. Hal tersebut kebutuhan masyarakat tentang informasi keuangan yang andal ini menyebabkan timbulnya profesi akuntan public atau auditor independen.

Auditor harus bersikap bebas untuk mereview dan menilai kebijaksanaan, rencana-rencana, dan prosedur serta catatan-catatan yang ada, sehingga auditor yang melakukan penilaian dan review harus terbebas dari pekerjaan rutin dalam organisasi sesuai dengan jabatan dan tanggung jawab yang diberikan menurut Kaunang (2012:07). Selanjutnya hal tersebut kesulitan dalam organisasi internal audit adalah menentukan jumlah auditor yang akan ditetapkan untuk bertanggung jawab dalam melaksanakan tugas dan menentukan tugas yang dibutuhkan harus mempertimbangkan bebrepa factor, diantaranya berap luas area yang akan diaudit, berapa jauh jangkauan pekerjaan audit akan dialkukan untuk suatu are tertentu,frekuensi pekerjaan audit yang diinginkan dan kebutuhan staf yang selalu stand by untuk Special assignment.

Menurut peraturan BPK Republik Indonesia No.1 tahun 2007 tentang standar pemeriksaan keuangan Negara, yang dimaksud dengan pemeriksa adalah orang yang melaksanakan tugas pemeriksaan pengelolaan dan tanggung jawab keuangan Negara untuk dan atas nama badan pemeriksa keuangan. Aparat pengawas internal pemerintah adalah init organisasi dilingkungan pemerintah pusat, pemerintah daerah, kementerian Negara, lembaga Negara dan lembaga pemerintah non departemen yang menpunyai tugas dan fungsi melakukan pengawasan dalam lingkup kewenangnya. Satuan pengawasan internal adalah unit organisasi pada badan usah milik Negara atau badan usaha milik daerah yang menpunyai tugas dan fungsi melakukan pengawasan dalam lingkup kewenangannya.

Dalam melaksanakan tugas auditor berhak mendapatkan segala informasi yang dibutuhkan untuk mendukung pendapat yang akan diberikan dan auditor sector public 
bertanggungjawab untuk merencanakan dan melaksanakan audit untuk menperoleh kayakinan memadai tentang apakah laporan keuangan organisasi bebas dari salah saji secara material baik yang disebabkan oleh kekeliruan atau kecurangan, auditor dapat menperoleh keyakinan memadai,namun bukan untuk, bahwa salah saji material terdeteksi menurut Bastian (2014:26).

\section{HASIL DAN PEMBAHASAN}

\section{Pengaruh Pengalaman Kerja Terhadap Kualitas Audit Internal}

Pengalaman kerja dapat memperdalam dan memperluas kemampuan kerja. Semakin sering seseorang melakukan pekerjaan yang sama, semakin terampil dan semakin cepat dia menyelesaikan pekerjaan tersebut. Semakin banyak macam pekerjaan yang dilakukan seseorang, pengalaman kerjanya semakin kaya dan luas, dan memungkinkan peningkatan kinerja (Simanjuntak, 2005:27). Hasil penelitian Herliansyah dkk (2006) menunjukan bahwa pengalaman mengurangi dampak informasi tidak relevan terhadap judgment auditor. Jadi dapat dikatakan bahwa seseorang jika melakukan pekerjaan yang sama secara terus menerus, maka akan menjadi lebih cepat dan lebih baik dalam menyelesaikannya. Hal ini dikarenakan dia telah benar-benar memahami teknik atau cara menyelesaikannya, serta telah banyak mengalami berbagai hambatan-hambatan atau kesalahan-kesalahan dalam pekerjaannya tersebut, sehingga dapat lebih cermat dan berhati hati menyelesaikannya. Hal yang sama penelitian yang dilakukan oleh Slamet (2012) Hasil penelitiannya menunjukkan bahwa pengalaman kerja dan kompetensi berpengaruh positif terhadap kualitas audit. Jadi semakin tinggi pengalaman kerja yang dimiliki auditor, maka semakin tinggi kualitas audit yang dihasilkan auditor independen dan semakin tinggi tingkat kompetensi auditor, maka semakin tinggi kualitas audit yang dihasilkan auditor independen. untuk dapat meningkatkan kompetensi Auditor maka pemberian pelatihan serta diberi kesempatan untuk auditor untuk mengikuti kursus atau peningkatan pendidikan profesi. Oleh karena itu auditor independen harus menjadi perhatian dalam pengalaman kerja dan kompetensi 
untuk menciptakan kualitas audit yang baik. Herliansyah dkk (2006) menyatakan bahwa secara spesifik pengalaman dapat diukur dengan rentang waktu yang telah digunakan terhadap suatu tugas (job) atau pekerjaan. Sedangkan hasil penelitian oleh Mohammed.S (2015) menunjukkan bahwa pengalaman kerja, integritas, kompetensi dan komitmen untuk organisasi memiliki pengaruh yang signifikan terhadap kualitas audit. Namu variable pengalaman kerja memiliki pengaruh paling dominan terhadap kualitas hasil audit.

Jadi dapat dikatakan bahwa seseorang apabila melakukan pekerjaan yang sama secara terus menerus, maka akan menjadi lebih cepat dalam menyelesaikan pekerjaan dengan baik disebabkan telah memahami teknik untuk penyelesaian dalam berbagai hambatan atau kesalahan-kesalahan yang dihadapinya.

\section{Pengaruh Akuntabilitas Terhadap Kualitas Audit Internal}

Feny Ilmiyati (2012) hasil penelitiannya mengunkapkan bahwa akuntabilitas dan kompetensi auditor berpengaruh positif terhadap kualitas audit, sehingga motivasi dan implementasi pertanggungjawaban sosial dalam diri auditor yang lebih besar serta kompetensi yang baik dari akuntan maka akan membuat semakin baik kualitas audit yang dihasilkan auditor. Sedangkan dalam penelitian Mardisar (2007), seseorang dengan akuntabilitas tinggi memiliki keyakinan yang lebih tinggi bahwa pekerjaan mereka akan diperiksa oleh supervisor/manajer/pimpinan dibandingkan dengan seseorang yang memiliki akuntabilitas rendah, dari hasil penelitian ini terbukti bahwa untuk subjek yang memiliki akuntabilitas tinggi, setiap mengambil tindakan lebih berdasarkan alasan-alasan yang rasional tidak hanya berdasarkan sesuatu itu mereka senangi atau tidak.

Olivia Furiady (2015). Hasil penelitian ini menunjukkan bahwa Kompetensi, Akuntabilitas dan Objektivitas memiliki pengaruh yang signifikan terhadap kualitas audit. Dengan meningkatkan kompetensi auditor, auditor memiliki pengetahuan yang lebih dalam dan memberikan penilaian yang lebih baik untuk mencapai kualitas audit. Akuntabilitas akan membuat auditor memberikan upaya terbaik dalam melakukan audit dan Objektivitas dapat membantu auditor untuk dapat bertindak adil tanpa dipengaruhi 
oleh tekanan dari pihak lain. Sedangkan David H. Sinason, (2000) membahas tentang teori dalam administrasi publik yang menunjukkan bahwa peningkatan akuntabilitas dalam sektor publik mempengaruhi auditor untuk menurunkan tingkat materialitas; sehingga dapat meningkatkan audit dan entitas sektor publik, serta akuntabilitas yang merupakan panduan untuk pengambilan keputusan auditor.

Akuntabilitas terkandung kewajiban untuk memberikan keterangan atau laporan terhadap tindakan yang telah dilakukan kepada pemberi mandat. Media pertanggungjawaban dalam konsep akuntablitas tidak terbatas pada laporan pertanggungjawaban saja, tetapi mencakup juga praktik-praktik kemudahan pada pemberi mandat untuk mendapatkan informasi. Dengan demikian, akuntabilitas akan tumbuh subur pada lingkungan yang mengutamakan keterbukaan sebagai landasan pertanggungjawaban. Akuntabilitas adalah bentuk dorongan psikis yang membuat seseorang bertanggung jawab semua tindakan dan keputusan yang diambil. Penelitian yang membuktikan adanya hubungan dan pengaruh akuntabilitas seseorang terhadap kualitas kerja.

Berdasarkan pendapat para ahli dan penelitian yang telah dilakukan maka dapat dibuat suatu krangka pemikiran sebagai berikut:

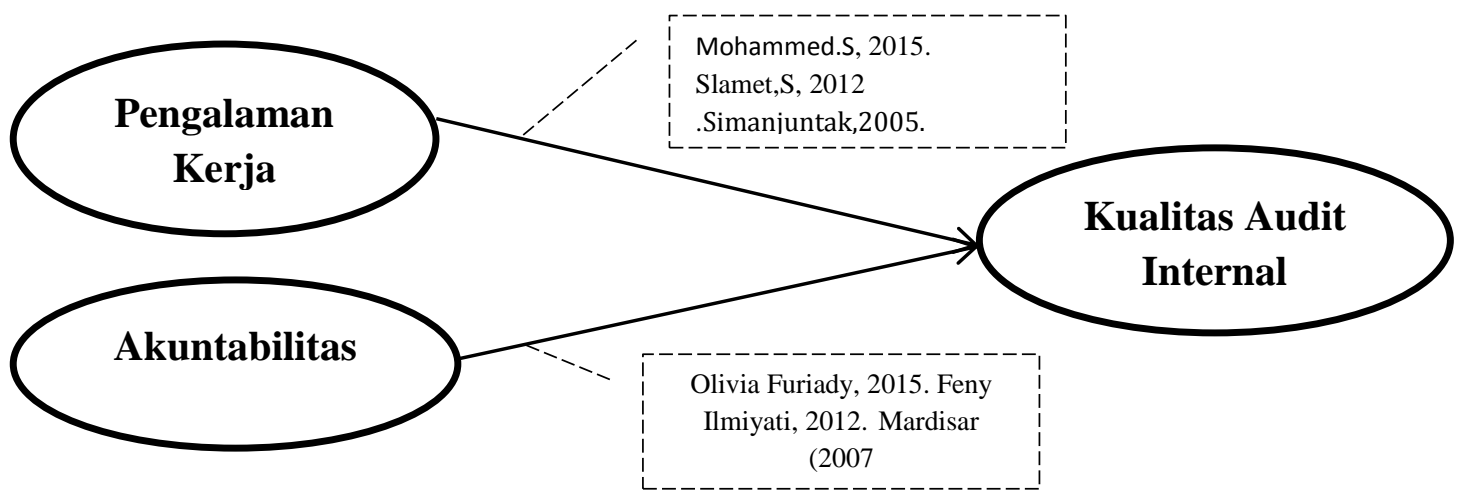

Figure 1. Theoretical Framework

\section{KESIMPULAN}


Berdasarkan analisis dari beberapa literature yang berupa konsep teori maupun penelitian-peneltian sebelumnya maka dapat diperoleh kesimpulan bahwa pengalaman auditor mempunyai pengaruh yang positif terhadap kualitas audit internal pada pemerintah daerah, oleh karena itu semakin banyak pengalaman yang dimiliki auditor internal maka semakin baik kualitas audit internal. Hal Demikian itu apabila seseorang melakukan pekerjaan yang sama secara berulang-ulang atau terus menerus, maka akan menjadi lebih cepat dan lebih baik dalam menyelesaikan audit, Oleh karena itu auditor telah benar-benar memahami teknik atau cara menyelesaikan audit dengan benar, dan telah banyak mengalami berbagai hambatan-hambatan atau kesalahan-kesalahan dalam pekerjaannya audit tersebut, sehingga dapat lebih cermat dan berhati hati menyelesaikan audit sesuai yang diharapkan. Hal tersebut berdasarkan dari uraian-urain yang telah dikemukakan maka semakin banyak pengalaman yang dimiliki oleh seoran auditor internal maka kualitas audit internal akan lebih meningkat.

Akuntabilitas merupakan suatu pengetahuan dan adanya pertanggungjawaban tehadap tiap suatu tindakan, produk, keputusan dan kebijakan termasuk pula di dalamnya administrasi publik pemerintahan, dan pelaksanaan dalam lingkup peran atau posisi kerja yang mencakup di dalamnya yang mempunyai suatu kewajiban untuk melaporkan, menjelaskan dan dapat dipertanyakan bagi tiap-tiap konsekuensi yang sudah dihasilkan. Hal demikian penelitian yang dilakukan oleh Mardisar (2007), bahwa seseorang dengan akuntabilitas tinggi memiliki keyakinan yang lebih tinggi bahwa pekerjaan mereka akan diperiksa oleh supervisor/manajer/pimpinan dibandingkan dengan seseorang yang memiliki akuntabilitas rendah, dari hasil penelitian tersebut terbukti bahwa untuk subjek yang memiliki akuntabilitas tinggi, setiap mengambil tindakan lebih berdasarkan alasanalasan yang rasional tidak hanya berdasarkan sesuatu itu mereka senangi atau tidak disenangi. Berdasrkan uraian tersebut dapat dikatakan bahwa akuntabilitas sangat kuat peranannya dan mempunyai pengaruh yang positif terhadap kualitas audit Internal.

\section{DAFTAR PUSTAKA}


Alvin A. Arens. 2012. auditing and Assurance Services,Person education limited.england

Arens, Alvin A., Randal J.E dan Mark S.B. 2004. Auditing dan Pelayanan Verifikasi, Pendekatan Terpadu. Jilid 1, Edisi Kesembilan. Penerbit PT.Indeks. Jakarta

Andayani Wuryan,2008, Audit internal, BPPFE-Yogyakarta.

Bastian Indra, 2014, Audit Sektor Publik,: pemeriksaan pertanggungjawaban Pemerintah,Salemba Empat, Jakarta.

Bawono, I.R. dan Elisha Muliani Singgih. 2010. Faktor-faktor dalam Diri Auditor

Dan Kualitas Audit: Studi Pada Kap 'Big Four' Di Indonesia. Jurnal Akuntansi \& Auditing Indonesia (Jaai) Issn 1410-2420.

David H. Sinason (2000 ) A Study Of The Effects Of Accountability And Engagement Risk On Auditor Materiality Decisions In Public Sector Audits, Auditing Standards (GAGAS), PrAcademics Press.

Dennis R. Arter, 2003. Quality Audits For Improved Performance, ASQ Quality Press Milwaukee, Wisconsin.

Feny Ilmiyati, (2012). Pengaruh Akuntabilitas Dan Kompetensi Auditor Terhadap Kualitas Audit (Studi Empiris Pada Kantor Akuntan Publik Di Semarang). Jurnal Juraksi universitas semarang-indonesia Vol. 1 No. 1 Januari 2012

Herliansyah, Yudhi, Meifida Ilyas. 2006. Jurnal. Pengaruh Pengalaman Auditor Terhadap Penggunaan Bukti Tidak Relevan Dalam Auditor Judgment. Sna Ix. PadangIndonesia.

Hiro Tugiman. Standar Profesional Audit Intern, 1997:11, Kanisius Yogyakarta.

Icuk, R. B dan Elisha, M. 2010. Jurnal. Pengaruh Independensi, Pengalaman, Due Professional Care Dan Akuntabilitas Terhadap Kualitas Audit (Studi pada Auditor di KAP "Big Four” di Indonesia). SNA XIII Purwokerto-Indonesia.

Karla M. Johnstone, (2014:15) Johnstone,Karla M.,Audrey A. Gramling. Larry E. Rittenberg. 2014. Auditing risk-Based Approach to Conductiong A quality Audit. South-western.

Kaunang F Alfred, 2012. Pedoman audit Internal:Petunjuk praktis bagi para auditor internal, Bhuana Ilmu popular, Jakarta.

Kurt F.R.,Paul J.S.,Urton L.A.,Michael.J.H. 2009, Internal Auditing: Assurance \& Consulting Services. Second edition by IIAF.Florida-USA 
Louwers, 2008. Auditing \& Assurance Service, McGRAW-Hill companies,America.

Mardisar. D dan R. Nelly Sari. 2007. Pengaruh Akuntabilitas dan Pengetahuan Terhadap Kualitas Hasil Kerja Auditor. Jurnal Simposium Nasional Akunatnsi X. MakassarIndonesia.

Mayangsari, S. (2003). Pengaruh Keahlian Audit dan Independensi terhadap Pendapat Audit, Jurnal Riset Akuntansi Indonesia. (6)1, 1-22.

Mohammed.S.Bouhawia,Irianto G,Baridwan Z. The Effect of Working Experience, Integrity, Competence, and Organizational Commitment on Audit Quality (Survey State 1( Owned Companies In Libya). IOSR-JEF UB Malang-Indonesia volume 6, Issue 4. Ver. II (Jul. - Aug. 2015), PP 60-67.

Mulyadi,2002. Auditing, salemba Empat. Jakarta.

Rick Hayes, 2005, PRINCIPLES OF AUDITING An Introduction to International Standards on Auditing, Second edition published by Pearson Education Limited

Robert Moeller, 1999, Brink's Modern internal auditing, Professional \& reference division jhon wiley \& sons, Canada.

Robert Moeller, 2005, Bring's modern internal auditing, jhon Wiley \& Sons in Canada.

Sembiring Andi Yahya dkk,2014. Pengaruh Pengalaman Dan Akuntabilitas Terhadap Kualitas Audit Internal Inspektorat Daerah Istimewa Yogyakarta, ejournal.uajy.ac.id/4867.

Setiawan Slamet, 2012. Pengaruh Pengalaman Kerja, Independensi, Dan Kompetensi Auditor Terhadap Kualitas Audit Oleh Akuntan Publik Di Surabaya.Jurnal Universitas katolik widya mandala Surabya-Indonesia.

Sukriah, Ika, Akram, Inapaty, B.a, 2009, Pengaruh Pengalaman Kerja, Independensi, Obyektivitas, Integritas dan Kompetensi terhadap Kualitas Hasil Pemeriksaaan, SNA XII, Palembang.

Sukrisno Agoes,2013. Auditing: Petunjuk praktis Pemeriksaan akuntan oleh Akuntan Publik,salemba Empat, Jakrta Selatan.

Olivia Furiady, Ratnawati Kurnia (2015) The Effect of Work Experiences, Competency, Motivation, Accountability and Objectivity towards Audit Quality, (GCBSS-2015) on "Multidisciplinary Perspectives on Management and Society", 17- 18 September, 2015, Bali, Indonesia. 
Peraturan Menteri Negara Pendayagunaan Aparatur Negara Nomor PER/05/M.PAN/03/2008 tentang Standar Audit Aparat Pengawas Intern Pemerintah.

Pusdiklatwas BPKP. 2005. Kode Etik dan Standar Audit. Edisi Keempat.

Yass Alkafaji \& Shakir Hussain, 2010, Characteristics of an Internal Audit Activity, The Institute of Internal Auditors Research Foundation (IIARF), 247 Maitland Avenue, Altamonte Springs, Florida

Yuliyanti Septi, Eddy Budiono, Pengaruh Independensi, Pengalaman, Due Professional Care, Dan Akuntabilitas Terhadap Kualitas Audit, https://repository.telkomuniversity.ac.id, diakses $t g l$ 28/02/2016 